\title{
The Implication of Authentic Assessment in Thematic Integrated Learning Process at Lower Level Elementary School
}

\author{
Taufina \\ Primary School Teacher Education Department \\ Universitas Negeri Padang \\ Padang, Indonesia \\ taufina@fip.unp.ac.id
}

\author{
Chandra \\ Primary School Teacher Education Department \\ Universitas Negeri Padang \\ Padang, Indonesia \\ chandra@fip.unp.ac.id
}

\begin{abstract}
Theassessment done focused on authentic assessment which is sought to assess the students' competence in terms of attitude, knowledge and skill. This research is classified into descriptive study. This research applied concurrent embedded models in which qualitative and quantitative models were applied disproportionately. The results of the research indicated that the integrated thematic learning assessment for the implementation of 2013 Curriculum at lower level Elementary Schools in Kabupaten 50 Kota had been done fairly well. The average score obtained before mentoring activities were done was 39,06 (low) while that after mentoring activities were done was 64,78 (quite good). Based on the result, it was concluded that the authentic assessment could be done during the learning process (process assessment) and after the learning process was done (product assessment).Nevertheless, it should be realized that, in Elementary School level, building the students' characters is more crucial than developing their academic ability.
\end{abstract}

Keywords-integrated thematic; 2013 curriculum; authentic assessment

\section{INTRODUCTION}

The purpose of this research was to see the teaching and learning process and the appropriateness between learning outcomes evaluation system and the requirements on the students' learning competence in 2013 Curriculum. As assessment is regarded as one of the components which is directly related to the curriculum, the development of assessment on student learning outcomes should be in line with the development of curriculum applied [1]. Nowadays, curriculum development requires the teachers to use authentic assessment. It is the process of gathering information about the progress and achievement made by the students by making use of a variety of techniques to reveal, to prove, or to show exactly that the learning objectives and the abilities (competencies) required have been completely mastered and achieved[2]. In other words, the authentic assessment is the process of describing the changes in students after the learning process takes place. Thus, the assessment is no longer simply the achievement of goals, but it is an attempt to obtain a variety of information on a regular basis which is done continuously and comprehensively on the learning process and on the student learning outcomes either in the aspects of attitude, knowledge or skill.

In authentic assessment, the assessment and the teaching and learning process are done integrally. It should reflect realworld problems, not the world of school. Authentic assessment used a variety of ways and holistic criteria which thoroughly reflects the students' knowledge, skill, and attitude. It does not only measure what is known by the students, but also reveal what can be done by thestudents[2]

The authentic assessment is developed because traditional assessment used before ignored the real-world context and less described the ability of the students holistically [3]. It was dominated by single method which was commonly in the form of written tests (cognitive). The written tests are much more about testing the students' ability to memorize factual information. They are used to assess the students' skills which are the fundamental part of learning, but they could not meet the demands of attitude, knowledge, and skill-based learning[4], [5].

Such scoring system frequently has negative impacts on the students. Although sometimes it could reflect the students' real ability, many people such as parents, teachers, and students make use of written tests as the standard of success. To improve the quality of such assessment, instruments that can accurately determine the ability of students in a lesson are needed. Without proper instruments of assessment, the students' ability will be solely determined based on the scores gotten from the test rather than the results of assessment from the beginning process until a product is produced by the students.

Based on 2013 Curriculum, the integrated thematic learning process in Elementary School (SD) level emphasizes on activities-based learning, and the assessment has greater emphasis on authentic assessment either in aspects of attitude, knowledge, or skill. Such assessment, in 2013 Curriculum is defined as a systematic process through which an authentic assessment requires an authentic teaching and learning process. According to Ormiston, an authentic teaching and learning process makes the assignments and problem-solving tasks done by the students related to the reality outside of 
school or daily life in general. Such assessment tends to require the students to accomplish complex and contextual tasks allowing them to clearly demonstrate their competence or skills. The examples of authentic assessment are job skills, the ability to apply or demonstrate specific knowledge, simulation and role playing, portfolio, selecting a strategic activity, and exhibiting and performing something[2].

Based on the results of mentoring activities and PLPG activities for elementary school teachers in Kabupaten 50 Kota, it was figured out that most of teachers got difficulties to conduct authentic assessment which emphasizes on assessing the students' attitude, knowledge and skill. The difficulties they faced were also described in the research conducted by Baharuddin[6]stating that the teachers still had problems to do assessment. This was supported by the data indicating that the teachers used less varied and discontinuous assessments. The instrument applied to assess the students' attitude was only in the form of observation sheet.

The assessments conducted by the teachers to assess the students' skills were merely based on the presentation done by the students in front of the class. Meanwhile to assess their knowledge, similar forms of assessment used in the previous curriculum were still applied. Therefore, a model of application of authentic assessment in integrated thematic teaching and learning process in Elementary School level was needed. Through this model, the teachers would get knowledge of developing the forms of assessment concerning with process and product assessments in terms of attitude, knowledge and skill in integrated thematic learning within the framework of 2013 Curriculum in Elementary School level in Kabupaten 50 Kota.

\section{METHODS}

This research could be classified into policy study which typically identifies various issues or problems that arise related to policy making. Through this research, the researcher analyzed the policy based on the data gathered. Furthermore, in the policy research, there are four variables that exert influence upon one to another, namely: (1) independent variable, (2) dependent variable, (3) interrupter variable, and (4) follower variable.

\section{RESUlTS AND DisCUSSIONS}

\section{A. The Results of Data Analysis on Assessment Done Prior to the Mentoring Activities}

There were five components discussed on the assessment sheet. Each component had similar category which was low. The score of the first, the second and the third descriptors was 42,9 (low). The teachers were not yet able to provide assessment instruments for competence aspect, were not yet able to adjust the assessment instruments to the techniques and the forms of authentic assessment, and were not yet able to adjust the assessment instruments to the indicators of competence. The score of the fourth and the fifth descriptors was 33,3 (low). This score indicated that the teachers were not yet able to make answer keys based on the test items provided and were not yet able to make scoring guidelines based on the test items. The results of data analysis on the assessment done before mentoring activities could be seen in the following table I.

TABLE I. THE RESUlTS OF DATA ANALYSIS ON THE ASSESSMENT DONE BEFORE MENTORING ACTIVITIES

\begin{tabular}{|c|c|c|c|}
\hline $\begin{array}{l}\mathrm{N} \\
\mathrm{O}\end{array}$ & Descriptors & $\begin{array}{c}\text { Score Teacher } \\
\text { Assessment }\end{array}$ & Category \\
\hline 1. & $\begin{array}{c}\text { The assessment } \\
\text { instruments for } \\
\text { competence aspect are } \\
\text { available }\end{array}$ & 42,9 & Low \\
\hline 2. & $\begin{array}{l}\text { The assessment } \\
\text { instruments are matched } \\
\text { to the techniques and the } \\
\text { forms of authentic } \\
\text { assessments }\end{array}$ & 42,9 & Low \\
\hline 3. & $\begin{array}{c}\text { The assessment } \\
\text { instruments are matched } \\
\text { to the indicators of } \\
\text { competence }\end{array}$ & 42,9 & Low \\
\hline 4. & $\begin{array}{c}\text { The answer keys based } \\
\text { on the test items are } \\
\text { available }\end{array}$ & 33,3 & Low \\
\hline 5. & $\begin{array}{l}\text { The scoring guidelines } \\
\text { based on the test items } \\
\text { are available }\end{array}$ & 33,3 & Low \\
\hline & Total & 195,3 & \\
\hline & Average & 39,06 & \\
\hline & Category & Low & \\
\hline
\end{tabular}

Explanation:

$$
\begin{aligned}
& \text { G1 : Teacher } 1=\text { YEL } \\
& \text { G2 : Teacher 2= RV } \\
& \text { G3 : Teacher 3 }=\text { MY }
\end{aligned}
$$

$$
\begin{aligned}
& \text { G4 }: \text { Teacher } 4=\mathrm{EP} \\
& \text { G5 }: \text { Teacher } 5=\mathrm{SL} \\
& \text { G6 }: \text { Teacher } 6=\mathrm{DES} \\
& \text { G7: Teacher } 7=\mathrm{TE}
\end{aligned}
$$

\section{B. The Result of Data Analysis on the Assessment Done after Mentoring Activities}

There were five components discussed on the assessment sheet after mentoring activities were done. The score of the respective component was varied and got increased. The score of the first, the second and the third descriptor was 76,2 (good). Two teachers had been able to make assessment instruments for competence aspect, had been able to match the assessment instruments to the indicators of competence, and had been able to design the assessment instruments in accordance to the techniques and forms of authentic assessment. Meanwhile 5 other teachers had less capability to make assessment instruments for competence aspects, had less capability to match the assessment instruments to the indicators of competence, and had less capability to design the assessment instruments in accordance to the techniques and forms of authentic assessment. The score of the fourth descriptor was 52,4 (low). There was only one teacher who was able to make answer keys. Two teachers made less appropriate answer keys and 4 teachers had not yet made answer keys. The score of the fifth descriptor was 42,9 (low). 
All of teachers had less capability to make scoring guidelines appropriately. 5 of them were not able to make the guidelines. The following table presents the result of data analysis on the assessment after mentoring activities were done.

TABLE II. The ResUlts of DATA ANALYSIS ON THE ASSESSMENT DONEAFTER MENTORING ACTIVITIES

\begin{tabular}{|c|c|c|c|}
\hline $\begin{array}{c}\mathrm{N} \\
\mathrm{O}\end{array}$ & Descriptors & $\begin{array}{c}\text { Score Teacher } \\
\text { Assessment }\end{array}$ & Category \\
\hline 1. & $\begin{array}{c}\text { The assessment } \\
\text { instruments for } \\
\text { competence aspect are } \\
\text { available }\end{array}$ & 76,2 & Good \\
\hline 2. & $\begin{array}{l}\text { The assessment } \\
\text { instruments are matched } \\
\text { to the techniques and the } \\
\text { forms of authentic } \\
\text { assessments }\end{array}$ & 76,2 & Good \\
\hline 3. & $\begin{array}{c}\text { The assessment } \\
\text { instruments are matched } \\
\text { to the indicators of } \\
\text { competence }\end{array}$ & 76,2 & Good \\
\hline 4. & $\begin{array}{c}\text { The answer keys based } \\
\text { on the test items are } \\
\text { available }\end{array}$ & 52,4 & Low \\
\hline 5. & $\begin{array}{l}\text { The scoring guidelines } \\
\text { based on the test items } \\
\text { are available }\end{array}$ & 42,9 & Low \\
\hline & Total & 323,9 & \\
\hline & Average & 64,78 & \\
\hline & Category & Adequate & \\
\hline
\end{tabular}

Explanation:
G1 : Teacher $1=$ YEL

G2 : Teacher 2= RV

G3 : Teacher 3= MY

\section{G4 : Teacher $4=\mathrm{EP}$ \\ G5: Teacher $5=$ SL \\ G6: Teacher $6=\mathrm{DES}$ \\ G7 : Teacher $7=\mathrm{TE}$}

\section{Integrated Thematic Learning Approach}

The reason for which integrated thematic learning approach is applied in the Elementary Schools is as it is appropriate to the students' development, the characteristics of learning, the concepts of learning and meaningful learning. [7]describes integrated thematic learning as webbed curricula through which he states that "webbed curricula represent the thematic approach to integrating subject matter. Typically, this thematic approach to curriculum development begins with a theme such as "transportations" or "inventions".,

Integrated thematic learning is an integrated learning which uses themes. It gives meaning to the students as a whole. In its implementation, the teaching and learning process is conducted by integrating several subjects by means of a theme[8]. Furthermore, the theme is a tool to introduce various concepts to the students as a whole [5]. In the teaching and learning process, the theme given is intended to bring together the contents of curriculum in a unity, enrich the students' vocabulary and give meaningful experience to the students. The integration in the teaching and learning process could be seen from the process or time aspect, the curriculum aspect, and the teaching and learning process aspect. Thus, the integrated thematic learning is a teaching and learning process which make use of themes to bring together the materials contained in several subjects which are then taught in single meeting[5].

Integrated thematic learning is an attempt to integrate knowledge, skills, values, or attitudes of learning and creative thinking by using themes[9]. Based on this notion, it can be summarized that the integrated thematic learning is conducted to improve and enhance the quality of education, particularly to balance the density of curriculum materials. In addition, integrated thematic learning will provide an integrated learning opportunities emphasizing on the students' participation or involvement in the teaching and learning process. The integration in the process could be seen from the aspect of the process or time, the aspect of the curriculum, and the aspect of the learning process.

The integrated thematic learning put more emphasis on the involvement of the students in the learning process actively, so that the students could directly experience the learning and were accustomed to construct the knowledge by themselves. Through direct experience, the students would understand the concepts being learned and be able to correlate them with the others which have already been acquired. This learning theory was firstly introduced by the formers of Gestalt psychology including Piaget who emphasizes that learning must be meaningful and oriented to the needs and the development of the children.

\section{Authentic Assessment}

Authentic assessment is a term used to describe various methods of alternative assessment that allow students to demonstrate their ability to complete tasks, to solve problems and to express their knowledge and skills by simulating situations encountered in the real world outside the school. Simulation in this case was the simulation that can express the students' achievement (performance) in the real world[8].

The principle of authentic assessment is the process of gathering information about the students' development and the achievement they make in the learning process by using a variety of techniques intended to exactly reveal, prove and show that the learning objectives and capabilities have been completely mastered and achieved[10]-[12].

Educational assessment is seen as a process of collecting and processing information to measure the students' achievement including authentic assessment, self-assessment, portfolio-based assessment, quizzes, daily tests, midterm test, and final semester test. (1) Authentic assessment is an assessment done comprehensively to assess attitude, knowledge and skill aspects started from input, process until output of learning. Authentic assessment is natural, facts based, and is not conducted in a depressed situation. (2) Selfassessment is an assessment carried out by the students reflectively to compare their relative position with the established criteria. (3) Portfolio-based assessment is an assessment conducted to assess the students' ability overally in the learning process, including individual and group 
assignments in and out of the classroom in a certain period. (4) Quiz is a process done to measure the students' progress and their learning achievement continuously (5) Daily test is an activity done to measure the students' competence periodically. (6) Midterm test is an activity done to measure the students' competence after 8-9 meetings were held. (7) Final semester test is an activity done to measure the students' competence at the end of the semester.

The assessment is conducted holistically covering attitude, knowledge and skill aspects in each level of education. It is done during the learning process (process assessment) and after the learning process ended (product assessment). In primary educational level, to build the students' characters is more important than to build their academic competence.

Based on the results of data analysis and discussion on the assessment before mentoring activity was done, and the results of data analysis and discussion on the assessment after mentoring activity was conducted, it was figured out that there was an improvement on the components studied in this research. In addition, the teachers' understanding on each component increased. These results imply that the application of authentic assessment which emphasizes on process and product assessment in integrated thematic learning is crucially needed. The teachers' less capability to apply such assessment could be overcome by providing an ongoing training. This could solve the difficulties faced by most of teachers in doing assessment in mentoring activities and PLPG activities in Kabupaten 50 Kota in applying 2013 Curriculum. The results of this research also could be applied to the teachers described as those who used less-varied and discontinuous assessment[6]. The training on designing assessment instruments for assessing the students' attitude, skill and knowledge could be done through ongoing and regular mentoring activities.

The assessment which is dominated by single method (written test) is only able to assess the students' ability to memorize factual information. It does not work well to determine the student's ability in terms of attitudes, knowledge, and skills [4]. The authentic assessment is developed in response to the imbalance assessment of the three aspects (attitudes, skills and knowledge), and as the traditional assessment done previously seemed to ignore realworld context and less describes the students' ability holistically[3]. Authentic assessment emphasizes on the student's ability to demonstrate their knowledge in a real and meaningful way[1]. In other words, authentic assessment requires the student to apply the knowledge they have already acquired in the form of skill-based activities interspersed with the demands of attitude.

\section{CONCLUSION}

The implementation of 2013 Curriculum requires the application of integrated thematic leaning in Elementary School level. It is believed that the integrated thematic learning is appropriate to the stages of the students' development, characteristics of learning, the concepts of learning and meaningful learning. The integrated thematic learning in Primary School level applied activities-based learning process. Thus, the assessment conducted emphasizes more on authentic assessment on attitude, knowledge, and skill aspects. It could be carried out during the learning process (assessment process) and after the learning process (product assessment). However, it should be realized that, in Elementary School level, building the students' characters is more crucial than developing their academic ability.

\section{Acknowledgment}

Authors would like to thank all those who contributed to completion of this article. Thanks also to the research fund provider, Universitas Negeri Padang.

\section{References}

[1] B. Nurgiyantoro, "Penilaian Otentik," Cakrawala Pendidik. Ed. Novemb. 2008, 2011

[2] P. RI, "Peraturan Menteri Pendidikan dan Kebudayaan Republik Indonesia Nomor 107 Tahun 2013 tentang Tunjangan Kinerja Bagi Pegawai di Lingkungan Kementerian Pendidikan dan Kebudayaan," 2013.

[3] H. Muchtar, "Penerapan Penilaian Autentik dalam Upaya Peningkatan Mutu Pendidikan," J. Pendidik. Penabur, vol. 14, no. 9, pp. 68-76, 2010.

[4] Nazar, Merancang Pembelajaran Aktif dan Kontekstual Berdasarkan “SISKO” 2006. Jakarta: PT Gramedia Widiasarana Indonesia, 2009.

[5] Kunandar, Guru Profesional Implementasi Kurikulum Tingkat Satuan Pendidikan (KTSP) dan Sukses dalam Sertifikasi Guru. Jakarta: Raja Pers, 2007.

[6] B. Baharudin, “Analisis Terhadap Kompetensi Pedagogik Guru dalam Pelaksanaan Pembelajaran dengan Pendekatan Saintifik di MI se Kota Bandar Lampung)," J. Terampil, vol. 3, no. 3, pp. 1-16, 2015.

[7] R. J. Fogarty and B. M. Pete, How to Integrate the Curricula. Corwin Press, 2009.

[8] K. Akbar, G. M. di SMP Negeri, and P. B. Daya, "Kurikulum 2013 dengan Pendekatan Scientific dalam Pembelajaran Matematika." 2016.

[9] S. Sungkono, "Pembelajaran Tematik dan Implementasinya di Sekolah Dasar," Maj. Ilm. Pembelajaran, vol. 2, no. 1.

[10] H. D. Brown, Language Assessment: Principles and Classroom Practices. Allyn \& Bacon, 2004.

[11] R. L. Taylor, Assessment of Exceptional Students: Educational and Psychological Procedures. ERIC, 2000.

[12] J. M. O’Malley, Authentic Assessment for English Language Learners Practical Approaches for Teachers. Addison: Wesley Publishing Company, 1996. 